\title{
Leadership in a Time of Transition: An Analogy between Post-exilic Judah/Yehud and Post- Apartheid South Africa ${ }^{1}$
}

\author{
DANIEL F. O'KeNNEDY (STELLENBOSCH UNIVERSITY)
}

\begin{abstract}
There are certain analogies between the post-exilic community in Judah (or Persian Yehud and post-apartheid South Africa. According to the OT two prominent leaders took responsibility for the rebuilding of post-exilic Judah/Yehud: the governor Zerubbabel and the high priest Joshua (cf. Ezra, Nehemiah, Haggai and Zechariah). Two prominent leaders made a major contribution in post-apartheid South Africa: president Nelson Mandela as political leader and archbishop Desmond Tutu as religious leader. This article will make a comparison between these two different communities and their leaders. The article will briefly discuss the respective leaders and will focus on the following analogies: both communities had an influential political leader and a religious leader; the diarchic model of leadership lasted only a few years in Judah/Yehud and in South Africa; the concept of forgiveness played a significant role in both communities (cf. Zech 3 and the Truth and Reconciliation Commission); there was a temple building process in Judah/Yehud and a process of nation building in South Africa.
\end{abstract}

KEYWORDS: Leadership; Joshua; Zerubbabel; Nelson Mandela; Desmond Tutu.

\section{A INTRODUCTION}

Nelson Mandela wrote the following note in 1998:

Men and women, all over the world, right down the centuries, come and go. Some leave nothing behind, not even their names. It would seem that they never existed at all. ${ }^{2}$

* Article submitted: 4/11/2016; peer-reviewed: 28/11/2016; accepted: 24/01/2017. To cite: Daniel F. O'Kennedy, "Leadership in a Time of Transition: An Analogy between Post-exilic Judah/Yehud and Post-Apartheid South Africa," Old Testament Essays 30/1 (2017): 128-150. Doi: http://dx.doi.org/10.17159/2312-3621/2017/ v30n1a8

1 A shorter version of this article was delivered as a paper at the IOSOT Congress in Stellenbosch, South Africa (4-9 September 2016).

2 Nelson Mandela, Nelson Mandela: Conversations with Myself (London: MacMillan, 2010), 403. 
This article focuses on leaders who made an impact on the history of two different communities in different continents with a time gap of more than 2500 years. According to the OT two prominent leaders took responsibility for the rebuilding of post-exilic Judah/Yehud: the governor Zerubbabel and the high priest Joshua. ${ }^{3}$ Two prominent leaders made a major contribution in postapartheid South Africa: president Nelson Mandela as political leader and archbishop Desmond Tutu as religious leader. After a few brief remarks on the socio-political background, I shall focus on the different leaders. In the last section I shall discuss a few possible analogies.

\section{B SHORT REMARKS ON SOCIO-POLITICAL BACKGROUND}

\section{Post-Exilic Judah/Yehud ${ }^{4}$}

Joshua and Zerubbabel were leaders during the post-exilic period of Jewish history. In 539 BCE the international scene changed when king Cyrus led Persia in displacing Babylon as the imperial power controlling the Mediterranean region. Cyrus made it Persian policy in 538 BCE to repatriate people that had been exiled to Babylon. He allowed the Judean exiles to return to Jerusalem and made the Judahite Shesbazzar the first governor and put him in charge of the building project (Ezra 5:14, 16). Cambyses, Cyrus's son, succeeded his father (530-522 BCE). At the end of his reign the Persian empire suffered with upheaval, and Cambyses died en route home from Egypt in an attempt to settle things down. Darius I, one of his officers claimed the throne and won the support of Cambyses' army in defeating a counter-claimant named Gaumata or Bardiya. Revolt spread, so it was not until 520 BCE that Darius established peace. ${ }^{5}$ During the reign of Darius I (522-486 BCE) the Persian empire comprised of territories from the Aral Sea and the western edge of the Himalayas to the Sahara, and from the Indus River Valley to the Danube. ${ }^{6}$

Darius was remembered for his administrative and trading skills. He organised his Persian empire in different protectorates or satrapies which

3 There are also similarities between the leadership of Zerubbabel and Joshua, and Nehemiah (governor) and Ezra (priest-scribe). In this article I shall focus on Zerubbabel and Joshua because they were leaders during a time of transition just as were Mandela and Tutu.

4 During the Persian period this province was called Yehud. In this article I shall refer to Judah/Yehud.

5 Pierre Briant, "History of the Persian Empire," in Forgotten Empire: The World of Ancient Persia, ed. John Curtis and Nigal Tallis (London: British Museum Press, 2005), 12-13; Paul L. Redditt, Introduction to the Prophets (Grand Rapids: Eerdmans, 2008), 317; Daniel F. O'Kennedy, "Haggai 2:20-23: Call to Rebellion or Eschatological Expectation?" OTE 27 (2014): 525.

6 Matt Waters, Ancient Persia: A Concise History of the Achaemenid Empire, 550330 BCE (New York: Cambridge University Press, 2014), 82. 
included smaller units or provinces. Judah, now called Yehud in Aramaic, was part of the fifth satrapy called Abar Nahara (Beyond the River). Yehud was ruled by a governor and consisted of a greatly reduced territory comprising of Jerusalem and its environments to a radius of about $25 \mathrm{~km}$. It was probably a sparsely populated province especially when compared to Judah before the Babylonian exile. $^{7}$

There is evidence in the $\mathrm{OT}^{8}$ that suggests there were conflict and tension between groups in Judah/Yehud during the time of Zerubbabel and Joshua. The nature of these tensions is more hinted at than discussed. There were possible conflicts over theological, ideological, political and economic issues. ${ }^{9}$ Communities usually consist of a great variety of groupings with different views. It is therefore not improbable that many different views and perspectives existed in the post-exilic community. ${ }^{10}$ However, one must not merely focus on the possible conflict. Kashow ${ }^{11}$ believes that the morale of the Judahites increased and expectations of restoration re-emerged after the appointment of Zerubbabel, a Davidic desecendant. The message of the prophets Haggai and Zechariah motivated the community to live with hope and encouraged them to complete the temple as a symbol of God's presence.

\section{Post-Apartheid South Africa}

Post-apartheid South Africa was established on 27 April 1994 with the first democratic elections. The ANC achieved $62 \%$ of the votes and Nelson

7 Pre-exilic Judah/Yehud had over 100000 inhabitants and scholars estimate between 10000 and 30000 in the Persian Period. However, there are a few scholars who view Yehud as a densely populated province. For a more detailed discussion see John Kessler, "Reconstructing Haggai's Jerusalem: Demographic and Sociological Considerations and the Search for an Adequate Methodoligcal Point of Departure," in "Every City shall be Forsaken": Urbanism and Prophecy in Ancient Israel and the Near East, ed. Lester L. Grabbe and Robert D. Haak, JSOTSup 330 (Sheffield: Sheffield Academic Press, 2001), 138-145; John Kessler, "Diaspora and Homeland in the Early Achaemenid Period: Community, Geography and Demography in Zechariah 1-8," in Approaching Yehud: New Approaches to the Study of the Persian Period, ed. Jon L. Berquist, SemeiaSt 50 (Atlanta: SBL, 2007), 139-141.

8 The books of Ezra-Nehemiah indicate that there was conflict between the returned exiles and the indigenous populations, including the non-exiled Judeans and the Samaritans in the north. Cf. Bill T. Arnold, Introduction to the Old Testament (New York: Cambridge University Press, 2014), 345.

9 Cf. Kessler, "Haggai's Jerusalem," 138-142 for the different variations of the socalled conflict model.

10 Willie J. Wessels, "The Tip of the Iceberg: Leadership and Leader Interaction in the Book of Haggai in a Time of Resettling and Reconstruction," OTE 16 (2003): 508-509.

11 Robert C. Kashow, "Zechariah 1-8 as a Theological Explanation for the Failure of Prophecy in Haggai 2:20-23,” JTS 64 (2013): 386. 
Mandela was inaugurated as the first democratic president on 10 May 1994 with FW de Klerk and Thabo Mbeki as deputy presidents. ${ }^{12}$ Technically we must acknowledge that the rebuilding process in South Africa already started on the 11th of February 1990 after the release of Nelson Mandela from prison.

Post-apartheid South Africa consists of nine provinces over a large geographical area of 1,221 million $\mathrm{km}^{2}$ and eleven official languages. In 1994 South Africa had a population of about 38.28 million people. There were tension and conflict during the first five years of Mandela's presidency but it was also for most South Africans a time of hope. People all over the world expected more violence and even war in post-apartheid South Africa, ${ }^{13}$ but the peaceful transition is described by many as a miracle.

\section{TWO INFLUENTIAL LEADERS IN POST-EXILIC JUDAH /YEHUD}

We must acknowledge that it is extremely difficult to evaluate these leaders due to a lack of extra-biblical documents. ${ }^{14}$ The following discussion is an attempt to form a picture of these influential leaders.

\section{Zerubbabel the Governor}

The name Zerubbabel is the Babylonian equivalent for the Hebrew which means literally "shoot/seed/offspring of Babylon." His name suggests that he was born in exile. ${ }^{15}$ Although we have several biblical verses ${ }^{16}$ referring to Zerubbabel mystery surrounds his origins as well as his end. In $1 \mathrm{Chr}$ 3:16-19 Zerubbabel is described as a grandson of the Davidic king Jehoiachin and most OT verses designate him as the son of Shealtiel. ${ }^{17} 1$ Chronicles 3:19 differs from these references and lists Pedaiah as Zerubbabel's father. There are different "solutions" for this contradiction: (1) there is an error in the MT and we should accept the LXX reading (the son of Shealtiel) in 1 Chr 3:19 as the correct rendition; (2) there are two different men called Zerubbabel; (3) these

12 Mandela, Conversations, 415; Rod Green, The Life of Nelson Mandela 1918-2013 (London: Constable, 2013), 181.

13 There were several incidents of severe violence before the 1994 elections: Boipatong massacre on 17 June 1992; assassination of Chris Hani on 10 April 1993; clashes between ANC members and members of the Inkhata Freedom Party, etc.

14 Erhard S. Gerstenberger, Israel in the Persian Period: The Fifth and Fourth Centuries BCE, BibEnc 8 (Atlanta: SBL, 2011), 101.

15 Schneir Levin, “Zerubbabel: A Riddle,” JBQ 24 (1996): 15; Gerstenberger, Israel in the Persian Period, 100.

161 Chr 3:19; Ezra 2:2; 3:2, 8; 4:2, 3; 5:2; Neh 7:7; 12:1, 47; Hag 1;1; 2:2, 20; Zech 4:6-7, 9-10. There is also one reference in 1 Esd 3:1-5:3 and another reference in Sir 49:11-12. Three NT verses include him in the genealogy of Jesus but these verses make no further comment about him (Matt 1:12, 13; Luke 3:27).

17 Cf. Ezra 3:2, 8; 5:2; Neh 12:1; Hag 1:1, 12, 14; 2:2, 3. 
are two different names for the same person; (4) the two names suggest a Levirate arrangement between Shealtiel's widows and Pedaiah due to the death of Shealtiel. ${ }^{18}$ The levirate hypothesis may be the best option, but there is still uncertainty. However, the textual evidence agrees that his grandfather was king Jehoiachin.

References in Ezra-Nehemiah (Ezra 2:2; Neh 7:7; 12:1, 47) portray Zerubbabel among those who had returned from Babylon after the exile. The precise date of Zerubbabel's arrival in Judah/Yehud is difficult to establish. ${ }^{19}$ He began his activities some time after the decree of Cyrus (538 BCE) and his name is explicitly mentioned for the last time in the second year of Darius (520 BCE). ${ }^{20}$

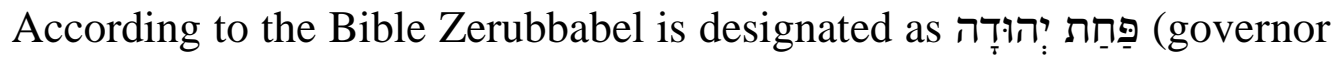
of Judah). This title appears four times in Haggai (Hag 1:1, 14; 2:2, 21) and in Neh 12:47 Zerubbabel's status is equated with that of Nehemiah. There is uncertainty about the authority and responsibilities of the governor but one can accept that the governor was officially appointed by the Persians to be responsible for administrative matters in a specific geographic area. It is probable that Zerubbabel as governor had the respect of the Persian leaders and that they assumed loyalty to them. ${ }^{21}$

We have mentioned that Zerubbabel was portrayed as a Davidic descendant because he was the grandson of the Davidic king Jehoiachin. The final oracle of Haggai describes Zerubbabel as YHWH's "servant" and "signet ring" (Hag 2:20-23). The designation "servant" or "servant of YHWH" is applied to a select group of divinely appointed figures in the OT: Abraham (Gen 26:24); Joshua (Judg 2:8; Josh 1:1, 7; etc.); David (2 Sam 7:5, 8; $1 \mathrm{Kgs}$ $11: 13 ; 14 ; 8 ; 2 \mathrm{Kgs} \mathrm{19:34);} \mathrm{and} \mathrm{others.}{ }^{22}$ The prophet Haggai does not use the political terms "king" or "prince," but rather the word "servant." Darius was already the Persian king and to have a similar claim of royal status for

18 Sara Japhet, "Sheshbazzar and Zerubbabel: Against the Background of the Historical and Religious Tendencies of Ezra-Nehemiah," ZAW 94 (1982): 71-72; Diana Edelman, The Origins of the "Second Temple": Persian Imperial Policy and the Rebuilding of Jerusalem (London: Equinox, 2005), 20-21; Mark J. Boda, The Book of Zechariah, NICOT (Grand Rapids: Eerdmans, 2016): 291-292.

19 Wolter H. Rose, Zemah and Zerubbabel: Messianic Expectations in the Early Postexilic Period (Sheffield: Sheffield Academic Press, 2000), 33-36.

20 According to Japhet, "Sheshbazzar," 71, Zerubbabel was a leader for a period of at least 17 years. Boda, Book of Zechariah, 13, suggests a date between 520 and 510 BCE.

21 Daniel F. O'Kennedy, "Haggai and Zechariah 1-8: Diarchic Model of Leadership in a Rebuilding Phase, " Scriptura 102 (2009): 584-585.

22 Greg Gosswell, "The Fate and Future of Zerubbabel in the Prophecy of Haggai," Biblica 91 (2010): 81. 
Zerubbabel would create unnecessary conflict. The ambiguity entailed in the use of the term "servant" enabled Haggai to reflect on the role of Zerubbabel, the Davidide without causing a political crisis. ${ }^{23}$ Besides the term "servant," Hag 2:23 portrays Zerubbabel as God's "signet ring" (חiֹתָם). The titles of "servant" and "signet ring" give him a subordinate role to God. Zerubbabel as Davidic king was expected to execute God's authority and represent God's interests. ${ }^{24}$ When these two terms are used together the redemptive role of the person so designated is enhanced all the more. It anticipates the eschatological rule of a righteous and just leader after the model of an idealised David. ${ }^{25}$

There are questions about the specific role of Zerubbabel, God's chosen signet ring. Scholars present divergent viewpoints: ${ }^{26} \mathrm{king}$ in a reconstituted nation; God's vice-regent; messianic figure. There is a strong possibility that the text of Hag 2:20-23 deliberately uses symbolic language to blur the future and therefore makes it impossible to delineate the reference in any detail.

Zerubbabel's name occurs four times in the book of Zechariah in oracles of encouragement (Zech 4:6, 7, 9, 10). In the visionary parts of Zech 4 there are no direct references to Zerubbabel but the symbolic language of the vision may refer indirectly to Zerubbabel. Verses 3 and 11 refer to the two olive trees and v. 12 to the two branches of the olive trees. ${ }^{27}$ Although his name does not appear in the rest of Zechariah many scholars (e.g. Boda, Meyers and Meyers, Petersen, Redditt, Rose) believe that the title צממֵ refers to Zerubbabel (Zech $3: 8 ; 6: 12){ }^{28}$

Unfortunately Zerubbabel disappeared from the scene and his name is not even mentioned at the dedication of the temple in 515 BCE (Ezra 6:15). ${ }^{29}$

23 David L. Petersen, Haggai and Zechariah 1-8, OTL (Philadelphia: Westminster Press, 1984), 106; Carol L. Meyers and Eric M. Meyers, Haggai, Zechariah 1-8, AB 25B (New York: Doubleday, 1987), 68-70.

24 Mark J. Boda, Haggai, Zechariah, NIVAC (Grand Rapids: Zondervan, 2004). 165.

25 Meyers and Meyers, Haggai, 1-8, 70; O'Kennedy, "Haggai and Zechariah 1-8," 532-534.

26 Cf. O’Kennedy, "Haggai and Zechariah 1-8," $535-536$ for a more detailed discussion.

27 O'Kennedy, "Haggai and Zechariah 1-8," 584.

28 Cf. the following scholars for a detailed discussion of the different viewpoints; Rose, Zemah, 248-249; James C. VanderKam, From Joshua to Caiaphas: High Priests after the Exile (Minneapolis: Fortress, 2004), 30-31; Al Wolters, Zechariah, (Leuven: Peeters, 2014), 193-196.

29 Three NT verses include him in the genealogy of Jesus (Matt 1:12, 13; Luke 3:27) but these verses make no further comment about him. 


\section{O'Kennedy, "Leadership in a Time," OTE 30/1 (2017): 128-150}

\section{$2 \quad$ Joshua $^{30}$ the High Priest}

There are at least nineteen OT passages ${ }^{31}$ that refer directly to the high priest Joshua, the son of Jehozadak. ${ }^{32} 1$ Chronicles 5:29b-41 depicts a genealogical list of the descendants of Aaron and it concludes with a reference to Joshua's father, Jehozadak. This list also identifies Seraiah, Joshua's grandfather, as the

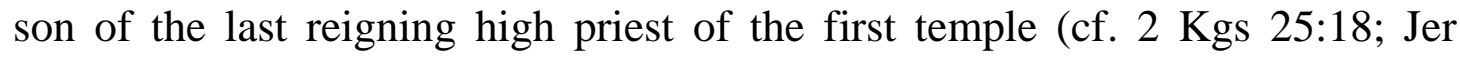
52:24). These references emphasise that Joshua was a member of the Zadokite priesthood and a descendent of Aaron. There is a strong possibility that the Persians knew of Joshua's religious background (Ezra 2:2). They must have seen him as a respectable religious leader and someone who would not cause too many problems for the Persian empire. ${ }^{33}$

According to the books Ezra-Nehemiah, Joshua was the leader of the first group that returned to Jerusalem from Babylon and began to work on rebuilding the temple (Ezra 2:2 $=$ Neh 7:7). He returned to Jerusalem at some unidentified time after $538 \mathrm{BCE}$. The book Ezra never refers to Joshua as the high priest, a fact which is in harmony with the tendency of the book to avoid titles. Nehemiah 12:10-12 depicts Joshua as the father of Joiakim who probably succeeded him as high priest. Ezra mentions that Joshua worked closely with Zerubbabel in re-establishing the worship of God in Jerusalem (Ezra 3:1-5), joined in starting construction of the second temple, and motivated the people to complete the temple (Ezra 3:1-13; 5:1-2; Hag 1-2). Joshua does not feature in the celebratory passage about the dedication of the temple (Ezra 6:15-22). ${ }^{34}$

The references in Haggai ${ }^{35}$ add little to what is said about Joshua in Ezra-Nehemiah apart from the fact that he is always identified by the title, the high priest (הַכּהָן הַגָּדוֹל). Joshua is mentioned second after Zerubbabel and he is not included in the oracle that closes the book (Hag 2:20-23). Joshua is not part of this eschatological scenario, but in the book of Zechariah he assumes a more prominent position in the visions of the future. ${ }^{36}$

30 Called Jeshua in the books of Ezra-Nehemiah.

31 Ezra 2:2; 3:2, 8; 4:3; 5:2; 10:18; Neh 7:7; 12:1, 7; Hag 1:1, 12; 2:2, 4; Zech 3:1, 3, $6,8,9 ; 6: 11$. There are other passages that may refer indirectly to Joshua.

32 Some translations and scholars use the spelling Jozadak.

33 Janet E. Tollington, Tradition and Innovation in Haggai and Zechariah 1-8, JSOTSup 150 (Sheffield: Sheffield Academic Press, 1993), 125-126; O’Kennedy, "Haggai and Zechariah 1-8," 583.

34 James C. VanderKam, "Joshua the High Priest and the Interpretation of Zechariah 3," CBQ 53 (1991): 553; Ralph W. Klein, "Were Joshua, Zerubbabel, and Nehemiah Contempories? A Response to Diana Edelman's Proposed Late Date for the Second Temple," JBL 127 (2008): 698-699.

35 Hag 1:1, 12, 14; 2:2, 4.

36 VanderKam, From Joshua, 21. 
The visions of Zechariah portray that the restoration of the priesthood after the exile begins with a specific high priest, Joshua $(3: 1,3,6,8,9)$. His guilt is taken away and he is clothed with festal apparel and a clean turban. Joshua is cleansed and forgiven in a rite performed in the divine council. The question may be posed: why did the high priest need forgiveness? Joshua is the representative of the post-exilic community in the face of YHWH. The high priest himself should be in a state of purity before he can be involved in the removing the guilt of others. As high priest Joshua is the one who connects the earthly human realm with the divine heavenly realm. According to Zech 3:8-9 a messianic announcement was delivered to Joshua that prophesied the coming of "my servant the Branch/Shoot" 37 who would finally remove the guilt of the land and people. ${ }^{38}$

The last OT reference to Joshua appears in the oracle or prophetic signact report of the two crowns (Zech 6:11). This oracle picks up the themes addressed in the fourth and fifth visions which introduces the leadership of Joshua and Zerubbabel respectively. ${ }^{39}$ Zechariah 6:11 portrays that a crown or crowns ${ }^{40}$ made of silver and gold was placed on the head of Joshua. There is a possibility that the oracle originally referred to both Zerubbabel and Joshua as recipients of these crowns. Perhaps there was a deliberate attempt in the text's redactional history to downplay Zerubbabel's role as political leader. However, the final form of Zech 6:9-15 leaves the impression that power was to be shared between Zerubbabel the political leader and Joshua the religious leader. ${ }^{41}$ VanderKam ${ }^{42}$ concludes with the following words concerning the status of Joshua:

Since Zerubbabel was the civil ruler, Joshua seems not to have exercised such authority outside the sphere of the sanctuary. Yet, the status of this high priest is more elevated vis-à-vis the Davidic leader than had been the case for his predecessors during the time of the First Temple.

37 Most English translations translate the Hebrew צֶמֵ term into "Branch" (cf. KJV, JB, NRSV, NIV, NJPS, NLT). Wolters, Zechariah, 101-102 argues that this translation is incorrect and prefers to transliterate the Hebrew word or translate it into "shoot."

38 Daniel F. O'Kennedy, "The Theological Portrayal of Forgiveness in Zechariah 18," Scriptura 84 (2003): 419; VanderKam, From Joshua, 24-25; James D. Nogalski, The Book of the Twelve: Micah-Malachi, SHBC (Macon, GA: Smyth \& Helwys Publishing, 2011), 845-850.

39 Boda, Book of Zechariah, 380-386.

40 MT reads the plural עַטָרָה (crowns).

41 Marvin A. Sweeney, The Twelve Prophets, vol. 2, BerOl (Collegeville, MN: Liturgical Press, 2000), 628-629; Nogalski, Micah-Malachi, 878-883.

42 VanderKam, From Joshua, 42. 

Joshua?

We have mentioned the possible conflict between different groups within the post-exilic community. The question remains: Was there also conflict between Zerubbabel and Joshua? There are scholars who argue that there was conflict between these two leaders and that Joshua and his followers were even responsible for Zerubbabel's death. ${ }^{43}$ One must accept that conflict is "normal" in any relationship. However, the biblical texts does not provide us with direct evidence of serious conflict between Zerubbabel and Joshua.

We rather find hints in the biblical texts that suppose a harmonious relationship. The names Zerubbabel and Joshua/Jeshua occur together twelve times in the OT. ${ }^{44}$ According to the biblical texts Zerubbabel and Joshua virtually never acted alone. ${ }^{45}$

There are references that suppose a balance of power, especially in the fourth vision of the golden lampstand (Zech 4). In v. 14, the climax of ch. 4, the בְני־הַיְָָּר (literally "sons of oil"). Many scholars ${ }^{46}$ argue that this phrase refers to Joshua and Zerubbabel. The fact that the two "sons of oil" are on the same level in relation to the lampstand expresses the equality of the two leaders. In the times of the monarchy the king was dominant, but in the new situation governor and priest are equals. Previously the king was spoken of as God's son, now there are two sons. ${ }^{47}$ The use of a particular Hebrew word הַיְֶָָ may also have another meaning besides that of bounty. According to Brown ${ }^{48}$ fresh oil represents a fresh beginning, consequently, leadership for the post-exilic community in Jerusalem is structured in a new way. Rather than the old form of royal dominance over the priesthood, a new model of leadership has emerged: royal and priestly figures are on equal ground.

43 J. Maxwell Miller and John H. Hayes, A History of Ancient Israel and Judah (Philadelphia: Westminster Press, 1986), 459; Levin, Zerubbabel, 17; Rainer Albertz, From the Exile to the Maccabees, A History of Israelite Religion in the Old Testament Period, vol. 2 (Göttingen: Vandenhoek \& Ruprecht, 1994), 453-454.

44 Cf. Ezra 2:2; 3:2, 8; 4:3; 5:2; Neh 7:7; 12:1; Hag 1:1, 12, 14; 2:2, 4.

45 Gosswell, "Fate and Future," 85.

46 Cf. Petersen, Haggai, 232-233; Meyers and Meyers, Haggai, 258-259; Eugene H. Merril, An Exegetical Commentary: Haggai, Zechariah, Malachi (Garland, TX: Biblical Studies Press, 2003), 140; VanderKam, From Joshua, 37; Nogalski, MicahMalachi, 858.

47 VanderKam, From Joshua, 37.

48 William P. Brown, Obadiah through Malachi, WestBC (Louisville, KY: Westminster John Knox Press, 1996), 152. 
Zechariah 6:9-15 further emphasises the harmonious relationship between Zerubbabel and Joshua. It seems plausible to see a picture of two thrones with two leaders sitting on them. They coexists "with peaceful understanding between the two of them" (Zech 6:13). ${ }^{49}$

Lastly, one can say that the prophets Haggai and Zerubbabel wouldn't advocate a diarchic model of leadership if there was serious conflict between them. Two leaders working against one another would not be the best for the temple rebuilding process. ${ }^{50}$

\section{$4 \quad$ What Happened to Zerubbabel and Joshua?}

Unfortunately Zerubbabel and Joshua disappeared from the scene. There is no OT reference to Zerubbabel after the description of his important role in the laying of the temple's foundation (Zech 4:9-10). In Ezra 5:3-6:15 the authority to rebuild the temple was questioned by Tattenai the governor of the province. King Darius gave his approval for the work to continue. However, no reference is made in the correspondence with the Persian court to Zerubbabel's presence. ${ }^{51}$ Ezra 5:2 portrays that Joshua and Zerubbabel were involved with the building of the temple. Their names are absent at the dedication of the temple in 515 BCE (Ezra 6:15). The biblical text does not portray that Zerubbabel and Joshua died and there are different hypotheses about the "disappearance" of these leaders. The first two hypotheses relate only to Zerubbabel while the last three relate to both leaders: ${ }^{52}$

(i) Some scholars believe that Zerubbabel was exterminated or removed from the office by the Persians. Waterman ${ }^{53}$ argues that the political propaganda of Haggai and Zechariah contributed to Zerubbabel's replacement as governor. This was done in the early period of Darius' reign when he was facing a series of rebellions by local rulers and therefore did not like this prediction. Some earlier interpreters claim that an actual rebellion took place under the leadership of Zerubbabel, leading to his execution. ${ }^{54}$ According to Albertz ${ }^{55}$ and Fleishman ${ }^{56}$ the

49 Tollington, Tradition and Innovation, 175-176; VanderKam, From Joshua, 40-41.

50 O'Kennedy, "Haggai and Zechariah 1-8," 588.

51 O'Kennedy, "Call to Rebellion," 527.

52 It is interesting to note that many scholars ignore the "disappearance" of Joshua, even VanderKam, From Joshua, 18-42 in his lengthy discussion of Joshua as the first post-exilic high priest. Scholars discuss the "disappearance" of Zerubbabel, but I believe the last three hypotheses could also explain the "disappearance" of Joshua.

53 Leroy Waterman, "The Camouflaged Purge of Three Messianic Conspirators," JNES 13 (1954): 73, 78. Cf. also Joseph Fleishman, "The Investigating Commission of Tattenai: The Purpose of the Investigation and its Results," HUCA 66 (1995): 88; Nogalski, Micah-Malachi, 796.

54 See discussion of Sarah Japhet, "Sheshbazzar," 78. 
suspicions of the Persians hastened the coming of Tattenai to examine the legitimacy of the building once they received the letter of the adversaries of the Jews. It is possible that as a result of the intervention of Tattenai the Persians removed Zerubbabel from his position as governor and even removed him from Judah.

(ii) The enigmatic passage in Zech 12:10 may suggest that Zerubbabel was killed by his own people in some type of struggle for power, perhaps by a pro-Davidic faction. ${ }^{57}$ Some scholars postulate that he was removed as governor by the priestly class led by Joshua, the high-priest. ${ }^{58}$ The question still remains: if Joshua was responsible for Zerrubbel's death why did he also disappear from the scene?

(iii) Zerubbabel and Joshua could have simply left their offices of governor and high priest peacefully, either due to old age or death from natural causes. ${ }^{59}$ It is however strange that the deaths of such prominent persons are never discussed. According to Lewis ${ }^{60}$ this mere fact lends itself to suspicion.

(iv) The fourth hypothesis presupposes that a narrative falling silent on a certain person is not uncharacteristic of the biblical narrative. ${ }^{61}$ The "disappearance" of Zerubbabel and Joshua is no mystery given the tendency of Ezra-Nehemiah to downplay the role of specific leaders. In Ezra 5 the names of the individuals (v. 2) are replaced by the general designation "the elders of the Jews" (v. 9). ${ }^{62}$

55 Albertz, History 2, 454.

56 Fleishman, "Investigating Commission," 89.

57 Miller \& Hayes, History of Ancient Israel, 459-460.

58 Cf. Albertz, History 2, 451-454; Levin, "Zerubbabel,” 17; Theodor J. Lewis, "The Mysterious Disappearance of Zerubbabel," in Seeking Out the Wisdom of the Ancients: Essays Offered to Honor Michael V. Fox on the Occasion of his Sixty-Fifth Birthday, ed. Ronald L. Troxel, et al. (Winona Lake, IN: Eisenbrauns, 2005), 308314.

59 Tamara C. Eskenazi, “Zerubbabel," NIDB 5: 980; Beyse argues that Zerubbabel died shortly after the completion but before the dedication of the second temple in 515 BCE. Cf. Karl-Martin Beyse, Serubbabel und die Königserwartungen de Propheten Haggai und Sacharja: Eine historische und traditionsgeschichtliche Untersuchung, AzTh 1/48 (Stuttgart: Calwer, 1972), 49.

60 Lewis, "Disappearance of Zerubbabel," 306-307.

61 Rose, Zemah, 34.

62 Cf. Gosswell, "Fate and Future," 85-86. The question is whether Ezra-Nehemiah downplayed the role or whether the elders took over the responsibilities of Zerubbabel and Joshua. Fleishman, "Investigating Commission," 89 believes that the elders took over the roles of Zerubbabel and Joshua. The leadership of the elders was also in accord with the pattern of the Persian administration which was based on teams. 
(v) Perhaps one can add a fifth hypothesis. Not only did the names of Zerubbabel and Joshua disappear from the biblical record, but also the name of Shesbazzar. He was the leader of the first group of returnees from Babylon and also the first in a series of governors of the Persian province Yehud. The information about other Judean leaders during the Persian period is also scarce. We do not really know what happened to Nehemiah and Ezra. ${ }^{63}$ Perhaps we can say that the biblical authors/redactors in the Persian period did not want to focus on the "permanent" role of the leaders but rather on the everlasting God and his temple in Jerusalem. It might be that they wanted to downplay the role of earthly leaders. ${ }^{64}$

All the above mentioned hypotheses are speculative. We simply do not know for what reason/s the texts are silent. There is not enough biblical or extra-biblical evidence to support any of these hypotheses. ${ }^{65}$

\section{How Long did the Diarchic Leadership of Zerubbabel and Joshua Last?}

It is difficult to determine the exact period of time that the diarchy lasted. In the above discussion I mentioned the following:

- Both leaders returned from exile after 538 BCE but the specific date is not mentioned. ${ }^{66}$

- They were still active in the second year of king Darius (520 BCE). ${ }^{67}$

- Neither Zerubbabel nor Joshua is explicitly mentioned in the narrative of the completion and dedication of the temple in 515 BCE (Ezra 6:14-18).

- There is no direct reference that indicates that Zerubbabel and Joshua were "removed" from the scene before the dedication and no references to their death.

The names of Zerubbabel and Joshua disappeared some time between the second year of Darius (520 BCE) and the dedication of the temple in 515

63 Gerstenberger, Israel in the Persian Period, 90-99.

64 A text like Zech 4:6 may support this hypothesis: "Not by might, not by power, but by my spirit, says the Lord of hosts."

65 Lewis, "Disappearance of Zerubbabel," 305 says the following: "Ultimately, this is a mystery we cannot solve. Arguments from silence by definition are speculative. Yet perhaps the silence of the one theory may be louder than the silence of another."

66 VanderKam, From Joshua, 20 argues that Joshua returned to Jerusalem at some unidentified time in Cyrus' reign between 538 and 530 BCE.

67 Boda, Book of Zechariah, 13 mentions that Zerubbabel's reign started at 520 BCE. (or earlier) and ends around 510 BCE. 
BCE. ${ }^{68}$ It is possible that the diarchic leadership lasted for only a few years. Although the period may have been short, lasting only a few years in the rebuilding phase of the post-exilic community, one can argue that it was perhaps the most significant period of the post-exilic community in Jerusalem.

\section{TWO INFLUENTIAL LEADERS IN POST-APARTHEID SOUTH AFRICA}

Everyone will agree that Nelson Mandela and Desmond Tutu played a significant role in post-apartheid South Africa. They did not merely play a role in South Africa but made an impact on the entire world. Both of them received the prestigious Nobel peace prize (Tutu in 1984 and Mandela in 1993) and they were described as two icons of reconciliation. ${ }^{69}$ Mandela and Tutu influenced one another but chose to focus on their respective roles as political and religious leader. We can now discuss their separate roles as leaders in postapartheid South Africa.

\section{$1 \quad$ President Nelson Rolihlahla Mandela ${ }^{70}$}

Rolihlahla ${ }^{71}$ Mandela was born on the 18th of July 1918 at Mveso, a tiny village on the banks of the Mbashe River in the Eastern Cape. His father Gadla Henry Mphakanyiswa, was a chief by blood and custom of Mvezu from the Thembu tribe. He was part of the Madiba clan. His mother was Nosekeni Fanny from the amaMpemvu clan and third of his father's four wives. ${ }^{72}$ The Mandela family later moved to the village of Qunu near Mthatha. In Qunu Mandela spent some of the happiest years of his boyhood and it is also the village where he was buried. ${ }^{73}$

In 1939 Nelson Mandela enrolled at the University of Fort Hare, but was expelled for embarking in protest action. He became an active leader in the

68 Fleishman, "Investigating Commission," 89; Rose, Zemah, 34.

69 Ben J. de Klerk, "Nelson Mandela and Desmond Tutu: Living Icons of Reconciliation," EcRev 55 (2003): 322-334.

70 In this article I shall mostly refer to his more familiar English name, Nelson.

71 The Xhosa name Rolihlahla means literally "pulling away or shaking the branch of a tree." His more familiar English name Nelson was given to him by the teacher of the primary school near Qunu. Cf. Nelson R. Mandela, Long Walk to Freedom: The Autobiography of Nelson Mandela (London: Abacus, 1994), 3; Mandela, Conversations, 412 . There were also other names given to him: Dalibhunga, the name given to him when he went through the Xhosa tribal initiation and Madiba, the clan name used as a term of respect. Cf. Rod Green, The Life of Nelson Mandela 19182013 (London: Constable, 2013), 6.

72 Mandela, Long Walk, 3-5.

73 Read more about Nelson's private life (marriages, children, family, etc.) in Mandela, Long Walk, his "official" autobiography. 
ANC and went to prison in 1963. In 1964 he and seven other comrades were convicted and sentenced to life imprisonment after the Rivonia trial. ${ }^{74}$

Nelson Mandela was released from prison after 27 years on the 11th February 1990. He received the Nobel Peace prize in 1993 and was elected as South Africa's first democratic president in 1994. The elections took place on the 27th of April and he was inaugurated on 10 May in Pretoria. President Mandela had the wisdom to step down in 1999 after just one term in office. ${ }^{75}$ Nelson Mandela still had a big influence in South Africa till his death on 5 December 2013 at the age of 95 years.

Nelson Mandela will be remembered for his character as human being, for his leadership and for the practical things he did in building a new democratic South Africa. Mandela really cared for all other human beings. He was even "accused" of being too much of a saint and being too good to all people. ${ }^{76}$ Mandela embodied the defiant belief in the worth and dignity of each person and the power and potential of transformation as the means of change. ${ }^{77}$ He was not only an icon of liberation. He will always be remembered as an icon of peaceful transition and reconciliation who really practiced what he preached. ${ }^{78}$

Evans $^{79}$ describes Mandela as a leader who exercised a profoundly integrated personal leadership that brought together clear and unswerving principles with deep and humane pragmatism. Ahmed Katrada, longtime friend and comrade of Nelson, singled out two exceptional leadership qualities of Mandela, namely courage and foresight. There were some times when he had to lead from the front, but he was always willing to listen to others. ${ }^{80}$

As an icon of reconciliation Mandela insisted that a journey into the deep recesses of South Africa's violent past should be undertaken. Under his presidency the Truth and Reconciliation Commission (TRC) was established. Meridith ${ }^{81}$ wrote the following: "No other episode during Mandela's presidency aroused so much controversy as the TRC." Unfortunately there were conflicting opinions about what the central purpose of a truth commission should be. There were also conflicting voices from his two deputy presidents.

\footnotetext{
74 Mandela, Long Walk, 361-362; Mandela, Conversations, 414.

75 Mandela, Conversations, 415.

76 Zelda la Grange, Good Morning, Mr Mandela (London: Penguin, 2014), ix.

77 Derek G. Evans, “In Memoriam: Reflections on Madiba,” JAAR 82/2 (2014): 4.

78 De Klerk, "Nelson Mandela," 326.

79 Evans, "Reflections on Madiba," 4.

80 Ahmed Kathrada, "Leadership," in Our Madiba: Stories and Reflections from those who met Nelson Mandela, ed. Melanie Verwoerd (Cape Town: Tafelberg, 2014), 244-245.

81 Martin Meredith, Mandela: A Biography (New York: Public Affairs, 2010), 551.
} 
Thabo Mbeki continued to insist that the TRC was "wrong and misguided." FW de Klerk accused the TRC of seeking vengeance, not reconciliation. Nelson Mandela made clear his support for the TRC and its work by emphasising that he was confident that the work of the TRC laid the foundation for the edifice of reconciliation. ${ }^{82}$

Mandela did not merely focus on reconciliation. The other pillar of Mandela's great legacy is his commitment to building a society that is socially, politically, and economically inclusive. He never lost sight of the goal of a nonracial democracy in South Africa. Nelson Mandela can really be described as the great includer. ${ }^{83}$ Mandela knew that difficult times would lie ahead for postapartheid South Africa, but he used his years as president to foster a climate of tolerance in the hope that it might take root permanently. ${ }^{84}$

As a practical leader Nelson Mandela promoted the physical reconstruction and development of South Africa. On the day before his inauguration (9 May 1994) he emphasised that South Africa needed a Reconstruction and Development Programme (RDP) that could be the cornerstone of building a better life of opportunity, freedom and prosperity. ${ }^{85}$

Nelson Mandela paved the way for other leaders to continue with the work of building a new democratic South Africa. He focused on the need for reconciliation during the years of transition. His successor Thabo Mbeki followed in his footsteps and put greater emphasis on the need to transform the South African society. ${ }^{86}$

\section{$2 \quad$ Archbishop Desmond Mpilo Tutu}

Desmond Mpilo Tutu was born on 7 October 1931 in a place called Makoeteng near Klerksdorp in the Northwest province. His father was a teacher and his mother a domestic worker. Desmond struggled with his health as a young child, which is why his grandmother called him Mpilo, or "health.",87

Desmond Tutu was a child of modern South Africa with a Motswana mother from the Sotho-Tswana language group and a Xhosa father. His

82 Meredith, Mandela, 563.

83 Evans, "Reflections on Madiba," 5; Peter Storey, "The Great Includer," ChrCent January 8 (2014): 11.

84 Meredith, Mandela, 573.

85 Albie Sachs, "Freedom in our Lifetime," in Nelson Mandela from Freedom to the Future: Tributes and Speeches, ed. Kader Asmal, David Chidester, and Wilmot James (Johannesburg: Jonathan Ball Publishers, 2003), 66-67.

86 Meredith, Mandela, 567.

87 Adrian Hadland, They Fought for Freedom: Desmond Tutu (Cape Town: Maskew Miller Longman, 2001), 5; John Allen, Rabble-Rouser for Peace: The Authorized Biography of Desmond Tutu (New York: Free Press, 2006), 9-10. 
mother's full-names were Aletta Dorothea Mavoertsek Mathlare, but most people called her Matse and her family called her Ausi ("big sister") Matse. The full-names of his father was Zachariah Zelilo Tutu, but he was known as ZZ. ${ }^{88}$

Tutu initially decided to follow a career as teacher but in 1958 he experienced the vocation to become a minister in the Anglican church. He continued his studies in England where he obtained a master of theology degree. ${ }^{89}$ In April 1986 Desmond Tutu was elected as archbishop of the Anglican Church in Southern Africa ${ }^{90}$ and enthroned in September of the same year. He acted as archbishop till 1996. Many people drew hope from Tutu becoming archbishop. $^{91}$ Because of the banning of the ANC and other liberation movements, Tutu had to fulfil two roles in South Africa before $1990,{ }^{92}$ the role of religious leader and political leader. Some called him the "political" priest. The apartheid government did not put him into prison and he was one of the few leaders who could publicly speak out against the unjust system of apartheid. However, Tutu was never interested in being a real political leader. He saw his role as a religious leader who could make a difference in South Africa.

Like Mandela, Tutu played a significant role as an icon of reconciliation in post-apartheid South Africa. One of his leading roles was to be the chairperson of the Truth and Reconciliation Commission (TRC). The work of the TRC was driven by three committees: (1) the Human Rights Violations Committee investigated human rights abuses occurring between $1960^{93}$ and 1994; (2) the Reparation and Rehabilitation Committee was charged with restoring victims' dignity and formulating proposals to assist with rehabilitation and reparation; (3) the Amnesty Committee considered applications from

88 Allen, Rabble-Rouser, 10-11. It is interesting to note that Desmond father's name was Zachariah Zelito, named after the biblical prophet Zechariah. The prophetic book of Zechariah is one of the main sources of information about Zerubbabel. The first black Anglican priest Desmond met also had the name of Zacharia Sekgaphane. Cf. Tiniyiko Maluleke, "Desmond Tutu's Earliest Notions and Visions of Church, Humanity, and Society," EcRev 67 (2015): 576.

89 De Klerk, "Nelson Mandela," 326.

90 Most people referred to the "Anglican Church," but the official name until 2006 was "Church of the Province of Southern Africa."

91 Hadland, Desmond Tutu, 36-37.

92 The release of Nelson Mandela from prison on 11 February 1990 was a precious moment for Tutu because he realised that his "political" role had come to an end. Cf. Desmond Tutu, No Future without Forgiveness (London: Rider, 1999), 2.

9321 March 1960 was the day 69 people were killed at Sharpeville by the apartheid government. Cf. Hadland, Desmond Tutu, 44. 
individuals who applied for amnesty in accordance with the provisions of the Act. $^{94}$

The first meeting of the TRC was held in 1995 on Reconciliation Day (16 December) and its public hearings started in April 1996 in East London. ${ }^{95}$ Some $21000^{96}$ victims had come forward to testify about their own ordeals or about the plight of others. In October 1998, the TRC released a final report of 3500 pages. The report was an extraordinary chronicle of what happened in South Africa between 1960 and $1994 .{ }^{97}$ Desmond Tutu said that the TRC in many ways summed up what his life was about, the healing of people. ${ }^{98}$

Desmond Tutu is a man who not only preaches forgiveness but embodies it. ${ }^{99}$ As a theologian Tutu believes in the goodness of God and human kind. He argues that in God's vision, sin is not the essential and foundational truth about human kind; goodness is the essential truth about human kind. According to Tutu we are not originally sinners, distant from God. We are originally the crowning achievement of creation. ${ }^{100}$ Kaunda ${ }^{101}$ summarises Tutu's role as a theologian in the following words:

Tutu has been one of South Africa's leading sociotheological praxis theologians esteemed for persistently calling for social justice, moral-ethical responsibility and social emancipation.

Desmond Tutu continues to expose social injustice and inequalities in post-apartheid South Africa and is a "watch critic" of the current government. He does not have the physical strength to fulfil an active role in society anymore but his mere presence is still an inspiration for many South Africans.

\section{How Long did the Diarchic Leadership of Mandela and Tutu Last?}

We can argue that there was an "unofficial" diarchy that lasted much longer than the "official" diarchy. The "official" diarchy started in 1995 when Tutu was the chairperson of the first TRC meeting on 16 December 1995 till the end

94 Hadland, Desmond Tutu, 45; Allen, Rabble-Rouser, 346.

95 Allen, Rabble-Rouser, 346.

96 Some 7000 people came forward to tell the truth and asked for amnesty, and 14000 victims told their stories. Cf. Hadland, Desmond Tutu, 45.

97 Hadland, Desmond Tutu, 47; Meredith, Mandela, 561.

98 Hadland, Desmond Tutu, 45.

99 Russel Botman, "The Embodiment of Forgiveness," in Tutu as I Know Him: On a Personal Note, ed. Lavina Crawford-Browne (Cape Town: Umuzi, 2006), 139.

100 Desmond Tutu and Mpho Tutu, Made for Goodness: And Why this Makes the Difference (London: Rider, 2010), 197.

101 Chammah J. Kaunda, "AA Voice Shouting in the Wilderness': Desmond Mpilo Tutu's Contribution to African Theology of Public Prophetic Preaching for Social Justice and Wholeness," IJPT 9 (2015): 29. 
of Mandela's term as president in 1999 (or the end of Tutu's term as TRC chair-person in 1998). The "unofficial" diarchy started earlier. Tutu met Mandela for the first time when he was a student at a teacher training college, and Mandela was the adjudicator in a debate. It was only a fleeting meeting and the next time they spoke was in February 1990 when Mandela came to stay at Bishop's Court the night after his release from prison. ${ }^{102}$ This "unofficial" diarcy lasted till Mandela's death on 5 December 2013.

Mandela and Tutu differed over certain issues but had the utmost respect for one another. ${ }^{103}$ All the people of South Africa could experience them working together towards their dream of a rainbow nation and New Democratic South Africa. Until Mandela's death their diarchy embodied mutual respect, co-operation and reconciliation.

\section{E POSSIBLE ANALOGIES BETWEEN LEADERSHIP IN POST- EXILIC JUDAH/YEHUD AND POST-APARTHEID SOUTH AFRICA}

We know that it is very difficult (perhaps impossible) to compare the two contexts and their leaders, but there are a few possible analogies:

- Both communities had a diarchy of an influential political and religious leader. Zerubbabel was the official governor appointed by the Persian empire and Joshua was the high priest of the Jews. Nelson Mandela was the elected state president of the new democratic South Africa and Desmond Tutu was the archbishop of the Anglican Church in Southern Africa ${ }^{104}$ and also the chairperson of the Truth and Reconciliation Commission. We know that the leaders fulfilled their different roles as political and religious leaders but in some instances the lines were not so clear. Some people even called Desmond Tutu the "political" priest. ${ }^{105}$ Perhaps one can also label Zerubbabel as the "priestly" politician. He was not only a political leader but also a key figure in the temple

102 Desmond Tutu, "Memories of Mandela," Nelson Mandela Foundation, 12 December 2013, https://www.nelsonmandela.org/news/entry/memories-of-mandelaarchbishop-desmond-tutu.

${ }_{103}$ Cf. Mandela, Long Walk, 78; Desmond Tutu, "Compassion," in Our Madiba, Our Madiba: Stories and Reflections from Those who met Nelson Mandela, ed. Melanie Verwoerd (Cape Town: Tafelberg, 2014), 44-45.

104 The Anglican Church was one of the largest churches amongst all South Africans and influential during the apartheid and post-apartheid years. According to the 1996 census the Zion Christian Church was the largest, but they were not so much involved in the "politics" of the day.

105 Michael Battle, Reconciliation: The Ubuntu Theology of Desmond Tutu (Cleveland, OH: The Pilgrim Press, 2010), 180. 
building process. There are even hints in the biblical texts that suppose a balance of power between Zerubbabel and Joshua (cf. Zech 4; 6:13).

- The diarchic model of leadership lasted only a few years in post-exilic Judah/Yehud and in post-apartheid South Africa. We do not really know how long Zerubbabel and Joshua served together as leaders, but it was a relatively short period of time. Nelson Mandela was the president of South Africa for one term of five years (1994-1999). Desmond Tutu acted as archbishop until 1996 and as chairperson of the TRC until 1998. Mandela had a big influence until his death in 2013 and Tutu is still a role-model for South Africans. Although the "official" diarchies in both communities did not last very long, we must acknowledge that their leadership made a significant impact during a time of transition.

- The concept of forgiveness played a significant role in both communities. According to Zech 3 the guilt of the high priest Joshua was taken away and he was clothed with festal apparel and a clean turban. Joshua is cleansed and forgiven as the representative of the postexilic community in the face of God. Archbishop Tutu was the chairperson of the Truth and Reconciliation Commission. Forgiveness is indispensable to the reconciliation process and played a significant role in post-apartheid South Africa.

- Zerubbabel and Joshua were actively involved in the temple building process. In South Africa Mandela and Tutu were involved in a process of building a new nation with new values. Nelson Mandela also launched the Reconstruction and Development Programme (RDP) in 1994. This programme helped with the physical building of millions of houses for the poor. ${ }^{106}$

\section{F POSSIBLE DIFFERENCES BETWEEN LEADERSHIP IN POST- EXILIC JUDAH/YEHUD AND POST-APARTHEID SOUTH AFRICA}

The following possible differences between leadership in post-exilic Judah and post-apartheid South Africa can be highlighted:

- Both Nelson Mandela and Desmond Tutu were described as icons of reconciliation. They fought for the reconciliation of all South Africans. At Nelson Mandela's inauguration he called South Africa the "rainbow nation of God." Desmond Tutu supported this idea of Mandela and

106 Between 1994 and the start of 2001 over 1.1 million houses were built. There is a difference between the "building process" in South Africa and post-exilic Judah/Yehud. Haggai prophesied to Joshua and Zerubbabel that the people should not merely focus on the rebuilding of their own houses, but that the temple was their first priority (cf. Hag 1:1-4). 
emphasised that peace, unity and harmony have to be worked at and nurtured. ${ }^{107}$ On the other hand Zerubbabel and Joshua did not fight for a rainbow nation. They separated the returned exiles from the other inhabitants. They did not want to work together with all the inhabitants of the Persian province of Yehud in the rebuilding of the temple. ${ }^{108}$

- Zerubbabel and Joshua were exiles in Babylon and returned to Judah after 538 BCE. Many influential South African leaders went into exile during the apartheid years and came back to South Africa just before the 1994 elections. Nelson Mandela and Desmond Tutu were not among those leaders. Nelson Mandela went to prison for 27 years and Desmond Tutu stayed in South Africa to help with the struggle for social justice.

\section{G CONCLUSION}

Everyone will agree that good leadership is crucial for every community, especially during times of transition. This article discussed possible analogies between leadership in the post-exilic community in Judah/Yehud and postapartheid South Africa. We focused on the role of Zerubbabel and Joshua, and Nelson Mandela and Desmond Tutu. We can learn a few lessons from the past and implement those lessons today. The question is: what are the lessons that we learned from leadership in these two communities? The above discussion leads us to emphasise the following:

- We need leaders from different spheres of life, not only political leaders. Religious leaders played a significant role in post-exilic Judah/Yehud and post-apartheid South Africa and can still play a significant role today.

- Leaders should work together as a team towards a common goal. Conflict between leaders can weaken their impact.

- It is important that leaders should serve all the inhabitants of a country or members of a community; not merely a certain group or section. Reconciliation and forgiveness are therefore very important.

- Leaders should be humble and not think too much of themselves. One leader should not have too much power; there must be a balance of power. From a religious perspective it is important that every leader should realise that the eternal God is the One who has the real power. Earthly leaders come and go.

107 Hadland, Desmond Tutu, 48.

108 Cf. Zvi Ron, "The First Confrontation with the Samaritans (Ezra 4)," JBQ 43 (2015): 117-118. 
- Leaders should embody what they believe like Mandela and Tutu who embodied reconciliation.

\section{BIBLIOGRAPHY}

Albertz, Rainer. From the Exile to the Maccabees. Vol. 2 of A History of Israelite Religion in the Old Testament Period. Göttingen: Vandenhoek \& Ruprecht, 1994.

Allen, John. Rabble-Rouser for Peace: The Authorized Biography of Desmond Tutu. New York: Free Press, 2006.

Arnold, Bill T. Introduction to the Old Testament. New York: Cambridge University Press, 2014.

Battle, Michael. Reconciliation: The Ubuntu Theology of Desmond Tutu. Cleveleand, OH: The Pilgrim Press, 2010.

Beyse, Karl-Martin. Serubbabel und die Königserwartungen de Propheten Haggai und Sacharja: Eine historische und traditionsgeschichtliche Untersuchung. AzTh 1/48. Stuttgart: Calwer, 1972.

Boda, Mark J. Haggai, Zechariah. NIVAC. Grand Rapids, MI: Zondervan, 2004. . The Book of Zechariah. NICOT. Eerdmans: Grand Rapids, MI: 2016.

Botman, Russel. "The Embodiment of Forgiveness." Pages 138-139 in Tutu as I Know Him: On a Personal Note. Edited by Lavina Crawford-Browne. Cape Town: Umuzi, 2006.

Briant, Pierre. "History of the Persian Empire." Pages 12-17 in Forgotten Empire: The World of Ancient Persia. Edited by John Curtis and Nigal Tallis. London: British Museum Press, 2005.

Brown, William P. Obadiah through Malachi. WestBC. Louisville, Kentucky: Westminster John Knox Press, 1996.

De Klerk, Ben J. "Nelson Mandela and Desmond Tutu: Living Icons of Reconciliation." EcRev 55 (2003): 322-334.

Edelman, Diana. The Origins of the "Second Temple": Persian Imperial Policy and the Rebuilding of Jerusalem. London: Equinox, 2005.

Eskenazi, Tamara C. “Zerubbabel.” Pages 980-981 in vol. 5 of The New Interpreter's Dictionary of the Bible. Edited by Katharine D. Sakenfeld. Nashville: Abingdon Press, 2009.

Evans, Derek G. "In Memoriam: Reflections on Madiba.” JAAR 82/2 (2014): 3-6.

Fleishman, Joseph. "The Investigating Commission of Tattenai: The Purpose of the Investigation and its Results." HUCA 66 (1995): 81-102.

Gerstenberger, Erhard S. Israel in the Persian Period: The Fifth and Fourth Centuries BCE. BibEnc 8. Atlanta: SBL, 2011.

Gosswell, Greg. "The Fate and Future of Zerubbabel in the Prophecy of Haggai." Biblica 91/1 (2010): 77-90.

Green, Rod. The Life of Nelson Mandela 1918-2013. London: Constable, 2013.

Hadland, Adrian. They Fought for Freedom: Desmond Tutu. Cape Town: Maskew Miller Longman, 2001.

Japhet, Sara. "Sheshbazzar and Zerubbabel: Against the Background of the Historical and Religious Tendencies of Ezra-Nehemiah." ZAW 94 (1982): 66-98.

Kashow, Robert C. "Zechariah 1-8 as a Theological Explanation for the Failure of Prophecy in Haggai 2:20-23." JTS 64 (2013): 386-403. 
Kathrada, Ahmed. "Leadership." Pages 243-245 in Our Madiba: Stories and

Reflections from those who met Nelson Mandela. Edited by Melanie Verwoerd.

Cape Town: Tafelberg, 2014.

Kaunda, Chammah J. “'A Voice Shouting in the Wilderness': Desmond Mpilo Tutu's

Contribution to African Theology of Public Prophetic Preaching for Social Justice and Wholeness." IJPT 9 (2015): 29-46.

Kessler, John. "Reconstructing Haggai's Jerusalem: Demographic and Sociological Considerations and the Search for an Adequate Methodoligcal Point of Departure." Pages 137-158 in "Every City shall be Forsaken": Urbanism and Prophecy in Ancient Israel and the Near East. Edited by Lester L. Grabbe and Robert D. Haak. JSOTSupp 330. Sheffield: Sheffield Academic Press, 2001. . "Diaspora and Homeland in the Early Achaemenid Period: Community, Geography and Demography in Zechariah 1-8." Pages 137-166 in Approaching Yehud: New Approaches to the Study of the Persian Period. Edited by Jon L. Berquist. Semeia Studies 50. Atlanta: SBL, 2007.

Klein, Ralph W. "Were Joshua, Zerubbabel, and Nehemiah Contempories? A

Response to Diana Edelman's Proposed Late Date for the Second Temple." JBL 127/4 (2008): 697-701.

La Grange, Zelda. Good Morning, Mr Mandela. London: Penguin, 2014.

Levin, Schneir. "Zerubbabel: A Riddle." JBQ 24/1 (1996): 14-17.

Lewis, Theodor J. "The Mysterious Disappearance of Zerubbabel." Pages 301-314 in Seeking Out the Wisdom of the Ancients: Essays Offered to Honor Michael V. Fox on the Occasion of his Sixty-Fifth Birthday. Edited by Ronald L. Troxel et al. Winona Lake, IN: Eisenbrauns, 2005.

Maluleke, Tiniyiko. "Desmond Tutu's Earliest Notions and Visions of Church, Humanity, and Society." EcRev 67/4 (2015): 572-590.

Mandela, Nelson Rolihlahla. Long Walk to Freedom: The Autobiography of Nelson Mandela. London: Abacus, 1994.

. Nelson Mandela: Conversations with Myself. London: Macmillan, 2010.

Meredith, Martin. Mandela: A Biography. New York: Public Affairs, 2010.

Merrill, Eugene H. An Exegetical Commentary: Haggai, Zechariah, Malachi.

Garland, TX: Biblical Studies Press, 2003.

Meyers, Carol L. and Eric M. Meyers. Haggai, Zechariah 1-8. AB 25B. New York: Doubleday, 1987.

Miller, J. Maxwell and John H. Hayes. A History of Ancient Israel and Judah. Philadelphia: Westminster Press, 1986.

Nogalski, James D. The Book of the Twelve: Micah-Malachi. SHBC. Macon, GA: Smyth \& Helwys Publishing, 2011.

O'Kennedy, Daniel F. "The Theological Portrayal of Forgiveness in Zechariah 1-8." Scriptura 84 (2003): 410-422.

. "Haggai and Zechariah 1-8: Diarchic Model of Leadership in a Rebuilding Phase." Scriptura 102 (2009): 579-593.

."Haggai 2:20-23: Call to Rebellion or Eschatological Expectation?" OTE 27/2 (2014): 520-540.

Petersen, David L. Haggai and Zechariah 1-8. OTL. Philadelphia: Westminster Press, 1984.

Redditt, Paul L. Haggai, Zechariah, Malachi. NCBC. Grand Rapids: Eerdmans, 1995. 
. Introduction to the Prophets. Grand Rapids: Eerdmans, 2008.

Ron, Zvi. "The First Confrontation with the Samaritans (Ezra 4)." JBQ 43/2 (2015): 117-121.

Rose, Wolter H. Zemah and Zerubbabel. Messianic Expectations in the Early Postexilic Period. Sheffield: Sheffield Academic Press, 2000.

Sachs, Albie. "Freedom in our Lifetime." Pages 51-92 in Nelson Mandela from Freedom to the Future: Tributes and Speeches. Edited by Kader Asmal, David Chidester, and Wilmot James. Johannesburg: Jonathan Ball Publishers, 2003.

Storey, Peter. "The Great Includer." Christian Century, January 8 (2014): 10-11.

Sweeney, Marvin A. The Twelve Prophets. Vol. 2. BerOl. Collegeville, MN: Liturgical Press, 2000.

Tollington, Janet E. Tradition and Innovation in Haggai and Zechariah 1-8. JSOTSup 150. Sheffield: Sheffield Academic Press, 1993.

Tutu, Desmond. No Future without Forgiveness. London: Rider, 1999.

. "Memories of Mandela." Nelson Mandela Foundation, 12 December 2013, https://www.nelsonmandela.org/news/entry/memories-of-mandela-archbishopdesmond-tutu.

. "Compassion." Pages 44-45 in Our Madiba: Stories and Reflections from those who met Nelson Mandela. Edited by Melanie Verwoerd. Cape Town: Tafelberg, 2014.

Tutu, Desmond and Mpho Tutu. Made for Goodness: And Why this Makes the Difference. London: Rider, 2010.

VanderKam, James C. "Joshua the High Priest and the Interpretation of Zechariah 3." CBQ 53 (1991): 553-570.

. From Joshua to Caiaphas: High Priests after the Exile. Minneapolis, Fortress. 2004.

Waterman, Leroy. "The Camouflaged Purge of Three Messianic Conspirators." JNES 13 (1954): 73-78.

Waters, Matt. Ancient Persia: A Concise History of the Achaemenid Empire, 550-330 $B C E$. New York: Cambridge University Press, 2014.

Wessels, Willie J. "The Tip of the Iceberg: Leadership and Leader Interaction in the Book of Haggai in a Time of Resettling and Reconstruction." OTE 16/2 (2003): 502-518.

Wolters, Al. Zechariah. HCOT. Leuven: Peeters, 2014.

Dr. Daniel F. O'Kennedy, Research Fellow and Part-timer Lecturer at the Department of Old and New Testament, Faculty of Theology, University of Stellenbosch.Email: danieok@nghelder.co.za. 